\title{
Research Article: Studies on spacing and time of planting on vegetative, floral and rhizome parameters of Alstroemeria cv. 'ALLADIN
}

\author{
IMTIYAZ TAHIR NAZKI, RAIZ AHMED LONE, GAZANFER GANI, MUNEEB \\ AHMAD WANI AND MADINAT UL NISSA
}

Article Chronicle: Received : 19.07.2017; Accepted : 03.08.2017

KEY Words: Alstroemeria, Date of planting, Spacing, Yield

Author for correspondence :

\section{IMTIYAZ TAHIR NAZKI}

Division of Floriculture and Landscape

Architecture, Sher-e-

Kashmir University of Agricultural Sciences and Technology, KASHMIR (J\&K) INDIA

Email : mitnazki@gmail. com

See end of the article for authors' affiliations
SUMMARY : A field experiment on different regimes of spacing and date of planting in growth, flowering and rhizome production of Alstroemeria cv. ALLADIN was conducted at the Experimental field of the Division of Floriculture and Landscape Architecture, Sher-e-Kashmir University of Agricultural Sciences and Technology of Kashmir, Shalimar, during 2008-2009. The 9 treatment combination consists of three regimes of spacing $\left(4,5\right.$ and 6 plants $\left.\mathrm{m}^{-2}\right)$ and three dates of planting $\left(3^{\text {rd }}\right.$ week of April, $\mathrm{I}^{\text {st }}$ week of May and $3^{\text {rd }}$ week of June). The result revealed that among different treatment combinations wider spacing resulted in significantly increased shoot emergence for the first three months. Thereafter, no significant effect of varied spacing on shoot number/plant was recorded. Earlier planting resulted in significantly more shoots per plant however, differences in shoot number per plant on account of varying planting dates evened out. The plants spaced at $4 \mathrm{~m}^{-2}$ yielded significantly more spikes than those spaced at 6 $\mathrm{m}^{-2}$. Highest total flower production per plant over one year period (57.578) was recorded with a spacing of 4 plants $\mathrm{m}^{-2}$ whereas highest total flower yield per unit area $\left(270.267 \mathrm{~m}^{-2}\right)$ was recorded with 6 plants $\mathrm{m}^{-2}$ spacing. 215.608 and 241.138 spikes $\mathrm{m}^{-2}$ were recorded with 5 and 4 plants $\mathrm{m}^{-2}$ spacing respectively. Spacing at 4 plants $\mathrm{m}^{-2}$ resulted in highest rhizome yield per plant $(0.319 \mathrm{~kg})$ as against 0. $292 \mathrm{~kg}$ with 6 plants $\mathrm{m}^{-2}$. Similarly rhizome number per plant was significantly higher in plants spaced at $4 \mathrm{~m}^{-2}\left(8.830\right.$ rhizomes per plant) as against 7.000 rhizomes per plant recorded with 6 plants $\mathrm{m}^{-2}$. However, 6 plants $\mathrm{m}^{-2}$ yielded highest rhizome weight $\left(1.719 \mathrm{~kg} \mathrm{~m}^{-2}\right)$ per unit area as compared to other spacing's.

How to cite this article : Nazki, Imtiyaz Tahir, Lone, Raiz Ahmed, Gani, Gazanfer, Wani, Muneeb Ahmad and Nissa, Madinat Ul (2017). Studies on spacing and time of planting on vegetative, floral and rhizome parameters of Alstroemeria cv. 'ALLADIN. Agric. Update, 12(TECHSEAR-7) : 2088-2091; DOI: 10.15740/HAS/AU/ 12.TECHSEAR(7)2017/2088-2091. 